\title{
Letter's recognition in early literacy through snakes and ladder games
}

\author{
Khairul Amri ${ }^{1}$, Rizkia Mauliza ${ }^{2}$, Syarfina ${ }^{3^{*}}$ \\ 1,2,3 Department of Islamic Early Childhood Education, Institut Agama Islam Negeri Langsa, Indonesia \\ ${ }^{*}$ corresponding author
}

\begin{tabular}{ccc}
\hline First received: & Revised: & Final Accepted: \\
18 November 2021 & 11 December 2021 & 28 December 2021 \\
\hline
\end{tabular}

\begin{abstract}
Skills in recognizing letters are indicators of a child's success in reading and building up their school readiness. However, learning media to introduce letters to early childhood still lacks creativity. This present study aims to determine the process of implementing the snakes and ladders games to increase children's letter recognition in early literacy. This research is a Classroom Action Research (CAR) using the Kemmis Taggart model. The respondents in this study were the 17 children aged 5-6 years in Pembina Kindergarten, Langsa, Indonesia. Data were collected by using observation and interview and analyzed descriptively. The researcher designed snake and ladder media printed in a big size and contained letters and pictures to implement the game. In addition, in playing snake and ladder of the letter, children become directly into pawns so that children play by involving the whole body. The results showed that the snakes and ladders game improved children's ability to recognize letters. In each cycle (first and second), there was a significant increase in achievement. Besides improving letter recognition, it was found that other development aspects could be stimulated by these games and increase children's motivation. Stimulation of language development apart from letter recognition can be studied further using this media to support early childhood literacy.
\end{abstract}

Keywords: Letter's recognition, early literacy, snakes and ladders games, early childhood education

\footnotetext{
${ }^{3}$ Corresponding Author:

Department of Islamic Early Childhood Education

Institut Agama Islam Negeri Langsa , Indonesia

Email: syarfina@iainlangsa.ac.id.
} 


\section{INTRODUCTION}

Skills in recognizing letters are one indicator of a child's success in reading as they get older (Heilmann et al., 2018). After a child leaves kindergarten, usually little time is devoted to teaching the alphabet, so children need to recognize letters and letter sounds in preschool to reduce difficulties during literacy activities (Tortorelli et al., 2017). The ability to recognize children's letters will appear when children are given pre-recognition experiences with letters. Then, reading readiness can be stimulated by prereading experience. If the pre-recognition letter experience is given at preschool age, it is hoped that the child will achieve reading.

However, learning to recognize letters should still pay attention to developmental characteristics and appropriate learning methods for children. Parents better not focus on teaching academic skills to prepare children ready to learn in elementary school (Fridani, 2020), thus ignoring the principle of playing while learning (Suyanto, 2005). The understanding of preschool teachers is essential in understanding the dimensions of children's school readiness (Syarfina et al., 2018). Teachers who understand will emphasize the essence of playing, which includes feelings of fun, independence, freedom to choose, and stimulating children to be actively involved. The learning returns to the basic principles of kindergarten education, namely as a playground, socialization, and the development of various abilities that are more substantial (Fauziddin, 2015). Hence, educators' efforts and guidance can help children reach the expected level of reading readiness.

In (Dhieni, 2014) Bromley explains that language consists of four aspects; listening, reading, speaking, and writing. Therefore, language is defined as an orderly symbol system for transferring various ideas or information consisting of visual and verbal symbols. In the Regulation of the Minister of National Education in 2014, the standard for the level of achievement of child development between the ages of 4-5 years states that language development includes the ability to use words both orally and in writing (Standar Pendidikan Anak Usia Dini, 2014). Especially in the scope of literacy, children are required to recognize symbols, make meaningful scribbles, and imitate the letter A-Z.

Writing activities for children start with simple words. In addition to writing according to the examples given by the teacher, letter recognition activities can also be carried out by connecting dotted lines that form a letter pattern (Dhieni \& Fridani, 2007). Children are welcome to make meaningful doodles. The achievement of the ability to recognize letters in preschool children is significant to note because it affects children's achievement when entering school. If the child already knows letters, then the child will quickly learn the next language level, such as writing sentences, reading, and quickly gain knowledge from reading a lot (Suharti, H., \& Supena, 2018).

he ability to recognize children's letters is also influenced by several factors, including the motivation that drives children's enthusiasm to recognize letters. This family environment acts as a model of behaviour or exemplary in recognizing letters, reading materials, or engaging media in introducing letters (Anderson, 2005). Strong motivation will encourage better success. Motivation can also be increased by designing 
media and activity scenarios that attract children's attention so that children are happy to pay attention to what is being taught.

However, the initial observations that the researcher made at the Pembina Kindergarten in Langsa City showed that the use of learning media to introduce letters to early childhood was still not optimal. It affects children's interest in participating in the learning process. The ability to recognize children's letters has not developed optimally. Children aged 4-5 years cannot recognize all the letters of the alphabet and have difficulty writing the letters. When mentioning the letter A-Z, students have difficulty distinguishing letters whose pronunciation or writing is almost the same, for example, "d" and "b", "f" and "v", "m" and "n", "p" and "q" and also "m" with "w". In addition, when mentioning a series of letters from a word and mentioning the first letter of a word, children tend to hesitate still.

In addition, the teacher carried out the activity of introducing letters with less attractive techniques and media. The teacher writes the noun to be introduced and then reads and says the word directly on the blackboard. So that children are interested in recognizing letters, teachers should use creative, innovative, and varied media. Creativity in making media is essential in learning so that children want to play an active role directly and not passively.

Based on the problem description, the researcher observes that this phenomenon needs to be minimized by conducting action research to introduce letters with an exciting game. One of the stimulations that stimulate the ability to recognize children's letters is using the snake and ladder game. With this letter ladder snake, it is hoped to increase the ability to recognize children's letters. The process of recognizing letters is the introduction of letters, sounds of letters, or a series of letters and understanding of meaning based on the context of discourse (Dhieni, 2014).

Sudarmanto \& Pamungkas (2012) conducted action research using the game of snakes and ladders, but the focus is on improving vocabulary recognition. Nouns were introduced to snakes and ladders media such as tables, chairs, blackboards, chalk, pens, pencils, bags, hats, shoes, marbles. The verbs are drawing, saving, planting, watering, learning, writing, counting, reading, and playing. Then the adjectives are beautiful, bad, small, big, high, low. In addition, there are also several studies on the use of snakes and ladders media to increase English vocabulary, integer operations, science lessons to increase children's learning motivation (Indriani et al., 2020; Khomsin \& Rahimmatussalisa, 2021; Utami et al., 2021; Widiana et al., 2019). However, no research underlines how to improve the ability to recognize children's letters through the snake and ladder learning media.

The media snake and ladder letters designed in this study contained letters accompanied by exciting pictures. The images provided correspond to the initial letters of the object's name. In addition, the advantage of this letter ladder snake is that children can explore directly into their pawns so that children play by involving the whole body. Media is printed in a size that children can step on. Through fun learning, children can learn actively so that children's abilities can increase (Moeslichatoen, 2005; Oktari, 2017). This 
study aims to determine the process of playing snakes and ladders letters in improving the ability to recognize letters in children aged $4-5$ years.

\section{METHOD}

The research design used is Classroom Action Research (CAR) with the Kemmis Taggart model, consisting of 4 stages: planning, action, observation and reflection. The subjects in this study were children aged 4-5 years in group A. This research was carried out at the Pembina State Kindergarten of Langsa City in two cycles for seven meetings.

The researcher prepares a lesson plan based on the subject and theme at the planning stage, namely recognizing letters. Planning includes formulating learning objectives, compiling learning steps, planning what teaching aids (media) are suitable for the subject to be taught from how to use them, and compiling evaluation tools following the objectives. Furthermore, at the action stage, the teacher teaches to see the ability to recognize initial letters using the snake and ladder game media that has been provided. During the learning activities, the researcher and the teacher of group A made observations and recorded events during the learning activities, which could later help make corrective decisions. An analysis of act one was carried out from the observations, followed by reflection. Based on the analysis and reflection results carried out together, it is planned to improve by taking action two on the existing problems.

Data collection techniques were used in the form of observation and interviews. The observation technique in this study was used to observe the learning activities of the research subjects. The observations were participant observations; in this case, the researchers observed letter learning activities using the snake and ladder media. The instrument used is an observation sheet to see indicators of recognizing letter symbols, making meaningful letter strokes, imitating by writing the letter AZ. Regarding the interview technique, the researcher conducted questions and answers to research informants openly according to a list of interview questions prepared previously. Then the results of the informants' answers were recorded for analysis.

This study uses two analytical techniques: quantitative descriptive statistical data analysis and qualitative data analysis. Quantitative data were obtained from observation scores assessed through pre-cycle, cycle I, and cycle II observation instruments. Quantitative data are presented in tables/graphs, analyzed using descriptive statisticsthe average value before and after getting the action to see the results of a proportion study. The success of the action is declared successful if the average percentage of the assessment class increases the ability to recognize children's letters by playing snakes and tanga above $80 \%$.

Qualitative data were analyzed from observations and interviews. In this study, the researcher analyzed the data that occurred in learning activities using the snake and ladder letter media from the initial observation to the implementation of the action. Data that emerge from qualitative data is in words, not a series of numbers. The qualitative data used is an interactive analysis technique developed by Miles and Huberman (2014). The interactive analysis consists of three components; data reduction, data presentation, and conclusion/verification. 


\section{RESULT AND DISCUSSION}

Pre-Cycle

The ability to recognize letters is observed based on three indicators, they are; (1) recognizing letter symbols, (2) making meaningful scribbles, (3) imitating (writing and mentioning the letter $\mathrm{AZ}$ ). The three indicators are assessed on a scale of undeveloped (Belum Berkembang/BB), starting to develop (Mulai Berkembang/MB), developing according to expectations (Berkembang Sesuai Harapan/BSH) and very well developed (Berkembang Sangat Baik/BSB). The following is a table of observations on the ability to recognize children's letters before the action:

Table I. Observation Result of Children's Letter Recognition Ability before Implementation

\begin{tabular}{|c|c|c|c|c|c|c|}
\hline Initial & $\begin{array}{c}\text { Indicator } \\
\text { I }\end{array}$ & $\begin{array}{c}\text { Indicator } \\
\text { II }\end{array}$ & $\begin{array}{c}\text { Indicator } \\
\text { III }\end{array}$ & Total Score & $\mathbf{\%}$ & Description \\
\hline AI & 2 & 2 & 1 & 5 & 1,6 & BB \\
\hline AK & 2 & 1 & 1 & 4 & 1,3 & BB \\
\hline AR & 2 & 2 & 1 & 5 & 1,6 & BB \\
\hline KA & 1 & 2 & 1 & 4 & 1,3 & BB \\
\hline KH & 1 & 2 & 2 & 5 & 1,6 & BB \\
\hline MA & 1 & 1 & 1 & 3 & 1 & BB \\
\hline MH & 2 & 1 & 1 & 4 & 1,3 & BB \\
\hline MI & 2 & 2 & 2 & 6 & 2 & MB \\
\hline MR & 2 & 1 & 1 & 4 & 1,3 & BB \\
\hline MS & 1 & 2 & 1 & 4 & 1,3 & BB \\
\hline MU & 2 & 2 & 1 & 5 & 1,6 & BB \\
\hline NA & 1 & 1 & 2 & 4 & 1,3 & BB \\
\hline NI & 2 & 2 & 1 & 5 & 1,6 & BB \\
\hline PR & 1 & 2 & 1 & 4 & 1,3 & BB \\
\hline RA & 1 & 1 & 1 & 3 & 1 & BB \\
\hline RY & 2 & 2 & 1 & 5 & 1,6 & BB \\
\hline SA & 2 & 1 & 1 & 4 & 1.3 & BB \\
\hline & 27 & 27 & 20 & 74 & & \\
\hline & $15 \%$ & $15 \%$ & $11,7 \%$ & $43 \%$ & & $74 \%$ \\
\hline & \multicolumn{2}{|l}{ Total score } & & & & \\
\hline & Total Children Achievement & & & & \\
\hline
\end{tabular}

The data in Table I shows that out of 17 children, $15 \%$ of children are said to recognize letter symbols correctly, while others still need help. On making meaningful scribbles, $15 \%$ of children can do it. On the indicator of imitation (writing and pronouncing the letter AZ) there are $11.7 \%$ of children achieve completeness. Based on these observations, it can be seen that the ability to recognize children's letters with an average achievement of $43 \%$ has not reached the expected percentage of $76 \%$ on each 
indicator. Moreover, based on the information on the children's success, there was only 1 child who reached the criteria MB while the other 16 children were in category BB. Therefore, to the need for an effective method (Throne, 2020), there is also an effective media in stimulating children's ability to recognize letters.

Cycle I

Cycle I consists of planning, implementation, observation and reflection stages. The implementation of the second cycle was carried out in 3 meetings. Based on the results of observations in the first cycle, the following data were obtained:

Table II. Observation Results of Ability to Recognize Letters in Cycle I

\begin{tabular}{|c|c|c|c|c|c|c|}
\hline Inittial & $\begin{array}{l}\text { Indicator } \\
\text { I }\end{array}$ & $\begin{array}{l}\text { Indicator } \\
\text { II }\end{array}$ & $\begin{array}{l}\text { Indicator } \\
\text { III }\end{array}$ & Total Score & $\%$ & Description \\
\hline AI & 2 & 2 & 2 & 6 & 2 & MB \\
\hline AK & 2 & 2 & 2 & 6 & 2 & $\mathrm{MB}$ \\
\hline AR & 2 & 3 & 2 & 7 & 2,3 & $\mathrm{MB}$ \\
\hline KA & 3 & 3 & 3 & 9 & 3 & $\mathrm{BSH}$ \\
\hline $\mathrm{KH}$ & 2 & 2 & 2 & 6 & 2 & $\mathrm{MB}$ \\
\hline MA & 2 & 3 & 2 & 7 & 2,3 & $\mathrm{MB}$ \\
\hline $\mathrm{MH}$ & 2 & 2 & 2 & 6 & 2 & $\mathrm{MB}$ \\
\hline $\mathrm{MI}$ & 3 & 4 & 3 & 10 & 3,3 & $\mathrm{BSH}$ \\
\hline $\mathrm{MR}$ & 2 & 2 & 2 & 6 & 2 & $\mathrm{MB}$ \\
\hline MS & 1 & 2 & 2 & 5 & 1,6 & $\mathrm{MB}$ \\
\hline MU & 2 & 2 & 3 & 7 & 2,3 & $\mathrm{MB}$ \\
\hline NA & 2 & 2 & 2 & 6 & 1,6 & $\mathrm{MB}$ \\
\hline NI & 2 & 3 & 2 & 7 & 2,3 & $\mathrm{MB}$ \\
\hline PR & 2 & 2 & 2 & 6 & 1,6 & $\mathrm{MB}$ \\
\hline RA & 2 & 2 & 2 & 6 & 1,6 & $\mathrm{MB}$ \\
\hline $\mathrm{RY}$ & 2 & 2 & 2 & 6 & 1,6 & $\mathrm{MB}$ \\
\hline SA & 2 & 2 & 3 & 7 & 2,3 & $\mathrm{MB}$ \\
\hline & 35 & 40 & 38 & 113 & & \\
\hline & $20,5 \%$ & $23,5 \%$ & $22 \%$ & $66,4 \%$ & & \\
\hline \multicolumn{4}{|c|}{$\begin{array}{c}\text { Total score } \\
\text { Total Children Achievement }\end{array}$} & \multicolumn{3}{|c|}{$\begin{array}{c}113 \\
66,4 \%\end{array}$} \\
\hline
\end{tabular}

The results of the ability to recognize children's letters in cycle I after the snake and ladder game action began to show an increase. The average score of children is $66.4 \%$, with the value of each indicator increasing more than before the action was implemented. The percentage on the child indicator mentions the letter symbol 20.5\%, makes meaningful scribbles $23.5 \%$, and on the imitation indicator (writes and says the letter AZ) $22 \%$. Although many children are still categorized as starting to develop (MB), namely 15 children, the children are getting excited. At that age, the child has a very high curiosity 
and quickly absorbs everything taught well if the teaching method or method is suitable for the child (Shofi, 2008).

Cycle II

The Cycle II intervention consisted of planning, implementing, observing, and reflecting stages. The implementation of the second cycle was carried out in 3 meetings. The following are the results of recognizing children's letters in the second cycle with the average percentage achieving completeness in table III.

Table III. Results of Observation of Children's Letter Recognition Ability Cycle II

\begin{tabular}{|c|c|c|c|c|c|c|}
\hline Resp.Inittial & $\begin{array}{c}\text { Indicator } \\
\text { I }\end{array}$ & $\begin{array}{c}\text { Indicator } \\
\text { II }\end{array}$ & $\begin{array}{c}\text { Indicator } \\
\text { III }\end{array}$ & $\begin{array}{l}\text { Total } \\
\text { Score }\end{array}$ & $\%$ & Description \\
\hline $\mathrm{AI}$ & 4 & 3 & 3 & 10 & 3,3 & $\mathrm{BSH}$ \\
\hline $\mathrm{AK}$ & 3 & 3 & 3 & 9 & 3 & $\mathrm{BSH}$ \\
\hline $\mathrm{AR}$ & 3 & 4 & 4 & 11 & 3,6 & BSB \\
\hline KA & 4 & 4 & 4 & 12 & 4 & BSB \\
\hline $\mathrm{KH}$ & 3 & 3 & 3 & 9 & 3 & $\mathrm{BSH}$ \\
\hline MA & 4 & 4 & 4 & 12 & 4 & BSB \\
\hline $\mathrm{MH}$ & 3 & 3 & 3 & 9 & 3 & $\mathrm{BSH}$ \\
\hline $\mathrm{MI}$ & 4 & 4 & 4 & 12 & 4 & BSB \\
\hline MR & 3 & 3 & 3 & 9 & 3 & $\mathrm{BSH}$ \\
\hline MS & 3 & 3 & 3 & 9 & 3 & $\mathrm{BSH}$ \\
\hline MU & 4 & 3 & 3 & 10 & 3,3 & $\mathrm{BSH}$ \\
\hline NA & 4 & 3 & 3 & 10 & 3,3 & BSH \\
\hline NI & 3 & 3 & 3 & 9 & 3 & $\mathrm{BSH}$ \\
\hline PR & 3 & 3 & 3 & 9 & 3 & $\mathrm{BSH}$ \\
\hline RA & 3 & 3 & 3 & 9 & 3 & $\mathrm{BSH}$ \\
\hline RY & 3 & 3 & 3 & 9 & 3 & $\mathrm{BSH}$ \\
\hline \multirow[t]{3}{*}{ SA } & 3 & 3 & 3 & 9 & 3 & $\mathrm{BSH}$ \\
\hline & 57 & 55 & 55 & 167 & & \\
\hline & $33 \%$ & $32 \%$ & $32 \%$ & $98 \%$ & & \\
\hline \multicolumn{4}{|c|}{$\begin{array}{c}\text { Total score } \\
\text { Total Children Achievement }\end{array}$} & \multicolumn{3}{|c|}{$\begin{array}{l}167 \\
98 \%\end{array}$} \\
\hline
\end{tabular}

Based on table III, it can be seen that the average score of students reached $98 \%$, with the criteria of 4 students developing very well (BSB) and 13 students developing according to expectations (BSH). With the percentage of indicators recognizing letter symbols (33\%), making meaningful scribbles (32\%), and imitating (writing and mentioning the letter AZ (32\%). Recognize letters that can be done conceptually, note grain theories related to acquiring the ability to know the letters (Dhieni \& Fridani, 2007). Put another game of snakes and ladders letter effectively as a medium of learning to introduce letters to children aged 5- 6 years.

Previously, the teacher had never applied the snake and ladder game to introduce letters to children. Snakes and ladders are games played by two or more people, the game board is divided into small boxes, and some of the boxes are drawn with several ladders or snakes that connect with other boxes (Mayesty, 1990). However, the researcher 
designed the letter ladder snake like a giant ladder snake that can be played with while walking or jumping. Therefore, Langsa City Pembina State Kindergarten teachers are very enthusiastic about teaching with this media. The children also really enjoyed playing with snakes and ladders in recognizing letters.

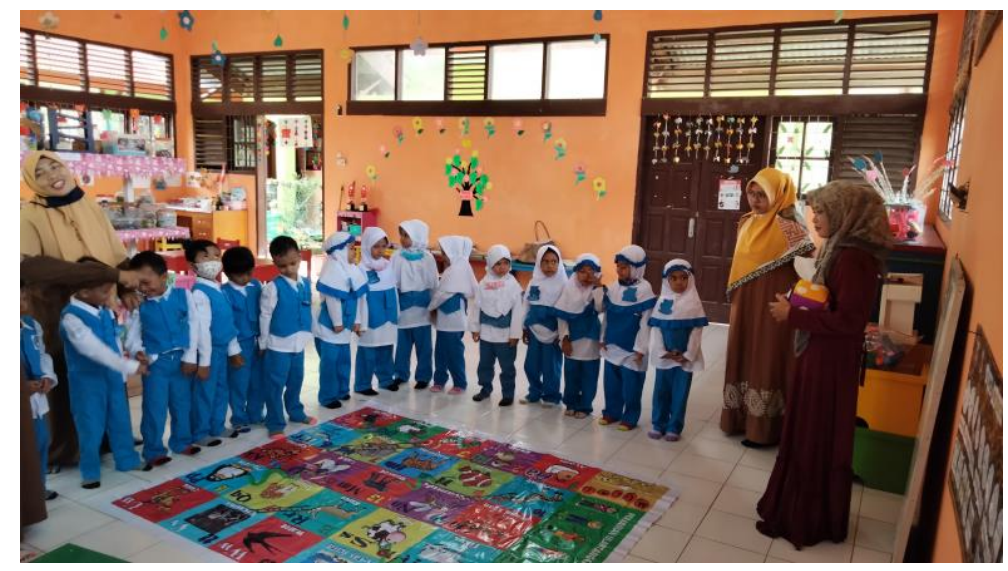

Figure I. Children start to play snakes and laddes game

The game of snakes and ladders also trains children's motor skills because children become pawns directly. In addition, the snake and ladder media is equipped with letters of the alphabet, and there are pictures of animals that match the theme being discussed. In addition to movement, children also see the various animals directly in the picture. If children's visual abilities develop well, it will significantly help their learning success (Anderson, 2005). Thus, the children participate in in-class activities with the snake and ladder game.

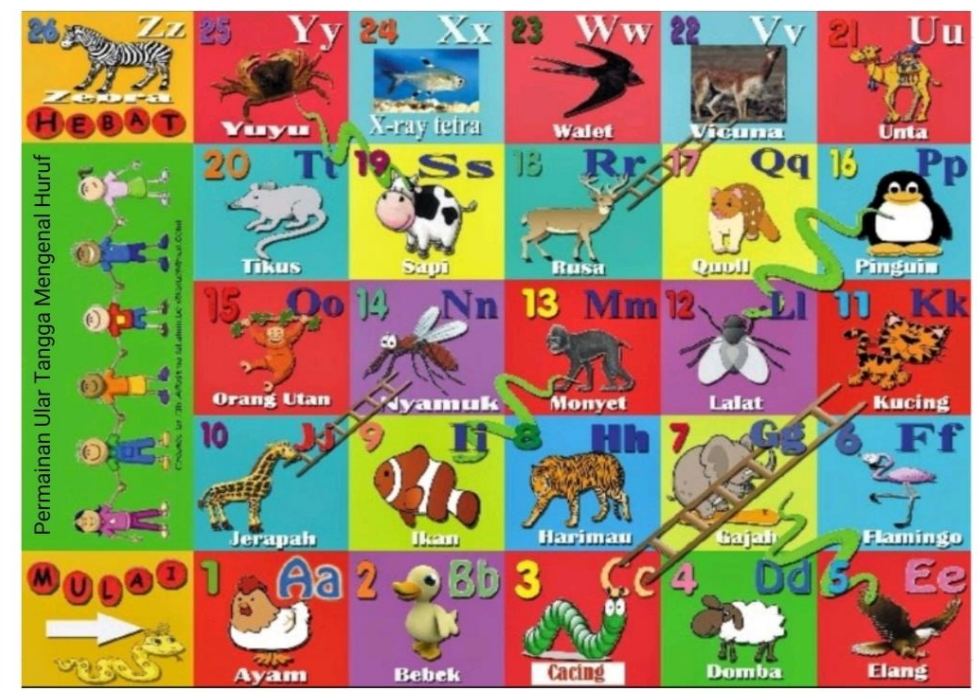

Figure II. Design of Snakes and Ladder Media

The following is a statement from the mother of one of the parents about the child's activity in recognizing letters through the game of snakes and ladders:

"Permainan ular tangga ini sangat menarik untuk digunakan, media nya sangat membantu anak-anak dalam mengenal huruf, dan juga mereka terlihat sangat antusias ketika diminta untuk melakukan permaianan ini sambil mengenal huruf. Dan juga, saya tertarik dengan 
permainan yang menggunakan pion dari anak nya sendiri sehingga lebih melatih motorik mereka dalam melakuykan kegiatan bermain dan anak cenderung tidak bosan. Selain itu, saya rasa permainan ular tangga ini juga dapat digunakan pada aktivitas yang lain seperti mengenal angka misalnya dan lain- lain." (Ibu RS)

(This snake and ladder game is exciting to use. The media is beneficial for children in recognizing letters. They also look very enthusiastic when asked to do this game while recognizing letters. Also, I am interested in games that use pawns from their children to train their motor skills in playing activities, and children tend not to get bored. In addition, I think this snake and ladder game can also be used in other activities such as recognizing numbers, for example, and others).

Based on this statement, it can be concluded that the game of snakes and ladders is very supportive of children's activities in recognizing letters. In addition, when researchers conducted interviews with children after finishing learning activities, almost all of their children liked and enjoyed playing snakes and ladders. So, this snake and ladder game effectively recognizes children's letters. Children's ability to recognize letters needs to be developed because this ability is fundamental to children's readiness when learning to read and write later (Marxen et al., 2008). Children aged 4-6 years have begun to remember letters that they often encounter, tell stories they have heard, recognize letters of the alphabet and are interested in various letters and readings in their environment (Suyanto, 2005).

Introduce letters to children; a fun learning system is needed, such as using the play method. This method was chosen to assume that learning is playing and playing while learning (Moeslichatoen, 2005). Snakes and ladders game can improve children's ability to recognize letters because the snake and ladder game has several advantages, including; (1) fun games for children, (2) developing children's language and increasing children's vocabulary, (3) stimulating children to solve simple problems, (4) develop interaction and communication between one child and another, (5) improve motor development of children (Fauziddin, 2015). The game of snakes and ladders can run well and can improve the ability to recognize children's letters because the teacher takes the steps as determined. In addition, the improvement of the results of the reflection cycle I, the holding of rewards and operational guidance by the teacher.

In the implementation of the second cycle, the method of the game was slightly changed the procedure for its implementation. They are using a competition model so that all children are actively involved. Children are enthusiastic about helping their friends find the same letters on the snake and ladder board so that the group wins. In addition, with group competition, children who have not been able will slowly recognize letters by working together. Games, if played in groups, can increase children's knowledge and motivation (Syarfina, 2020). Therefore, this snake and ladder letter media can not only improve children's ability to recognize letters, but it can also increase children's motivation. Increasing the ability to recognize letters through the game of snakes and ladders has succeeded in increasing up to $98 \%$ with excellent criteria. Therefore, the game of snakes and ladders can improve children's ability to recognize letters. 


\section{CONCLUSSION}

The creativity of researchers in designing snakes and ladders media is a crucial factor in increasing children's ability to recognize letters. In this study, the researcher designed snake and ladder media printed in a big size and contained letters and pictures. In playing snake and ladder, children become pawns to play by involving the whole of their body. In addition to improving children's ability to recognize letters, this game also increases children's motivation to learn. Other developmental aspects such as physical motor, cognitive, social-emotional can also be stimulated. Hopefully, other parts of language development are developed besides letter recognition, which can be studied further using this media to support early childhood literacy.

\section{REFERENCES}

Anderson, R. . (2005). Pemilihan dan Pengembangan Media Untuk Pembelajaran. Universitas Terbuka dan Pusat Antar Universitas.

Dhieni, N. (2014). Metode Pengembangan bahasa. Universitas Terbuka.

Dhieni, N., \& Fridani, L. (2007). Metode Pengembangan Bahasa: Hakikat Pengembangan Bahasa Anak. IKIP Veteran.

Fauziddin, M. (2015). Pembelajaran Paud. PT Remaja Rosdakarya.

Fridani, L. (2020). Mothers' perspectives and engagements in supporting children's readiness and transition to primary school in Indonesia. Education 3-13, 1-12. https://doi.org/10.1080/03004279.2020.1795901

Heilmann, J. J., Moyle, M. J., \& Rueden, A. M. (2018). Using Alphabet Knowledge to Track the Emergent Literacy Skills of Children in Head Start. Topics in Early Childhood Special Education, 38(2), 118-128. https://doi.org/10.1177/0271121418766636

Indriani, A., Junarti, J., \& Hidayah, U. L. (2020). Penerapan Permainan Ular Tangga pada Operasi Bilangan Bulat Siswa Sekolah Dasar. Jurnal Pendidikan Edutama, 7(1), 57. https://doi.org/10.30734/jpe.v7i1.713

Khomsin, \& Rahimmatussalisa. (2021). Efektivitas Media Permainan Ular Tangga untuk Meningkatkan Kemampuan Mengenal Kosakata Bahasa Inggris pada Anak Usia Dini Khomsin 1, Rahimmatussalisa 2 ARTICLE INFO ABSTRACT. Jurnal Pendidikan Anak, 10(1), 25-33.

Marxen, C. E., Ofstedal, K., \& Danbom, K. (2008). Early childhood teacher education policy: Linking teacher educators and policy makers. Journal of Early Childhood Teacher Education, 29(1), 81-88. https://doi.org/10.1080/10901020701878693

Mayesty, M. (1990). Creative Activites for Young Children 4 th Ed: Play, Development, and Creativity,. Delmar Publisher Inc. 
Miles, M. ., Huberman, A. ., \& Saldana, J. (2014). Qualitative Data Analysis, A. Methods Sourcebook, Edition 3. Sage Publications.

Moeslichatoen, R. (2005). Metode Pengajaran di Taman Kanak- Kanak. Rineka Cipta.

Oktari, V. M. (2017). Penggunaan Media Bahan Alam Dalam Pembelajaran Di Taman Kanak-Kanak Kartika I-63 Padang. PAUD Lectura: Jurnal Pendidikan Anak Usia Dini, Vol 1 No 1 (2017): Paud Lectura, 49-57.

Standar Pendidikan Anak Usia Dini, Pub. L. No. Permendikbud, 26 (2014).

Shofi, U. (2008). Sayang, Belajar Baca Yuk!. Surakarta: Afra Publishing.

Sudarmanto, \& Pamungkas, J. (2012). Peningkatan Kosakata Benda Melalui Permainan Ular Tangga pada Kelompok B di TK Pertiwi Tamanagung Muntilan. Jurnal Pendidikan Anak, 1(2).

Suharti, H., \& Supena, A. (2018). The Importance of Pre-Reading Ability in Early Childhood: Between Theory and Realit. International Journal of Advances in Scientific Research and Engineering (Ijasre), 41-45.

Suyanto, S. (2005). Konsep Dasar Pendidikan Anak Usia Din. Departemen Pendidikan Nasional.

Syarfina, S. (2020). Kemampuan mahasiswa dalam mengembangkan alat permainan edukatif berbasis perkembangan anak: Peran kelompok belajar APE. Atfāluna: Journal of Islamic Early Childhood Education, 3(1), 23-33. https://doi.org/10.32505/atfaluna.v3i1.1639

Syarfina, S., Yetti, E., \& Fridani, L. (2018). Pemahaman Guru Pra-Sekolah Raudhatul Athfal (Ra) Tentang Kesiapan Sekolah Anak. JPUD - Jurnal Pendidikan Usia Dini, 12(1), 153-163. https://doi.org/10.21009//jpud.121.13

Throne, K. L. (2020). Effective Methods of Alphabet Instruction for Preschool.

Tortorelli, L. S., Bowles, R. P., \& Skibbe, L. E. (2017). Easy as AcHGzrjq: The Quick Letter Name Knowledge Assessment. Reading Teacher, 71(2), 145-156. https://doi.org/10.1002/trtr.1608

Utami, E., Pangestika, R. R., \& Ratnaningsih, A. (2021). Penerapan Media Ular Tangga Untuk Meningkatkan Hasil Belajar Siswa Pada Pembelajaran Matematika Kelas Iv Sd Negeri Bayan. Jurnal Pendidikan Dasar, 2(2), 106-113. http://jurnal.umpwr.ac.id/index.php/jpd

Widiana, I. W., Parera, N. P. G., \& Sukmana, drianus I. W. I. Y. (2019). Media Permainan Ular Tangga Untuk Pengetahuan Ipa. Journal of Education Technology, 3(4), 315322. 